\title{
AD-A236 689
}
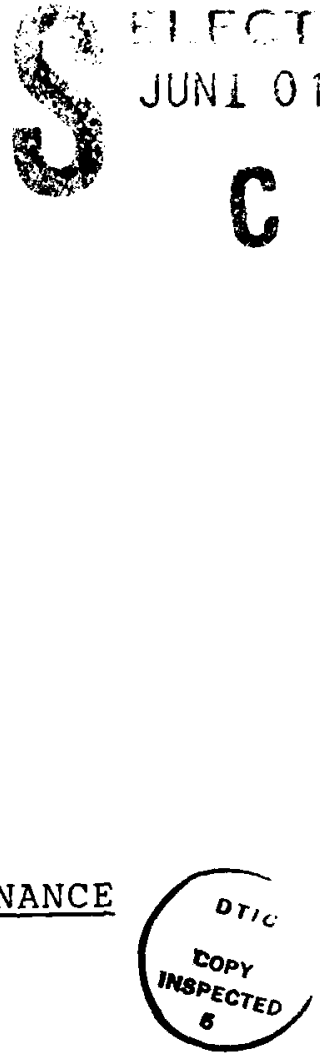

MAJOR JOSEPH G. HILL

U.S. ARMY

11 FEBRUARY 1991

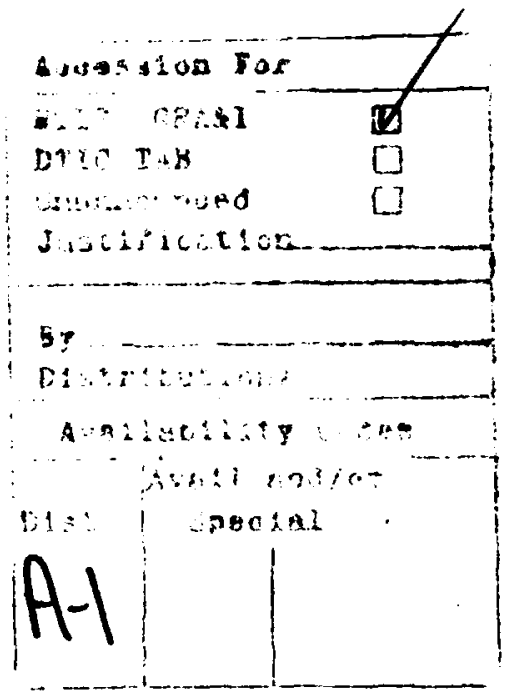




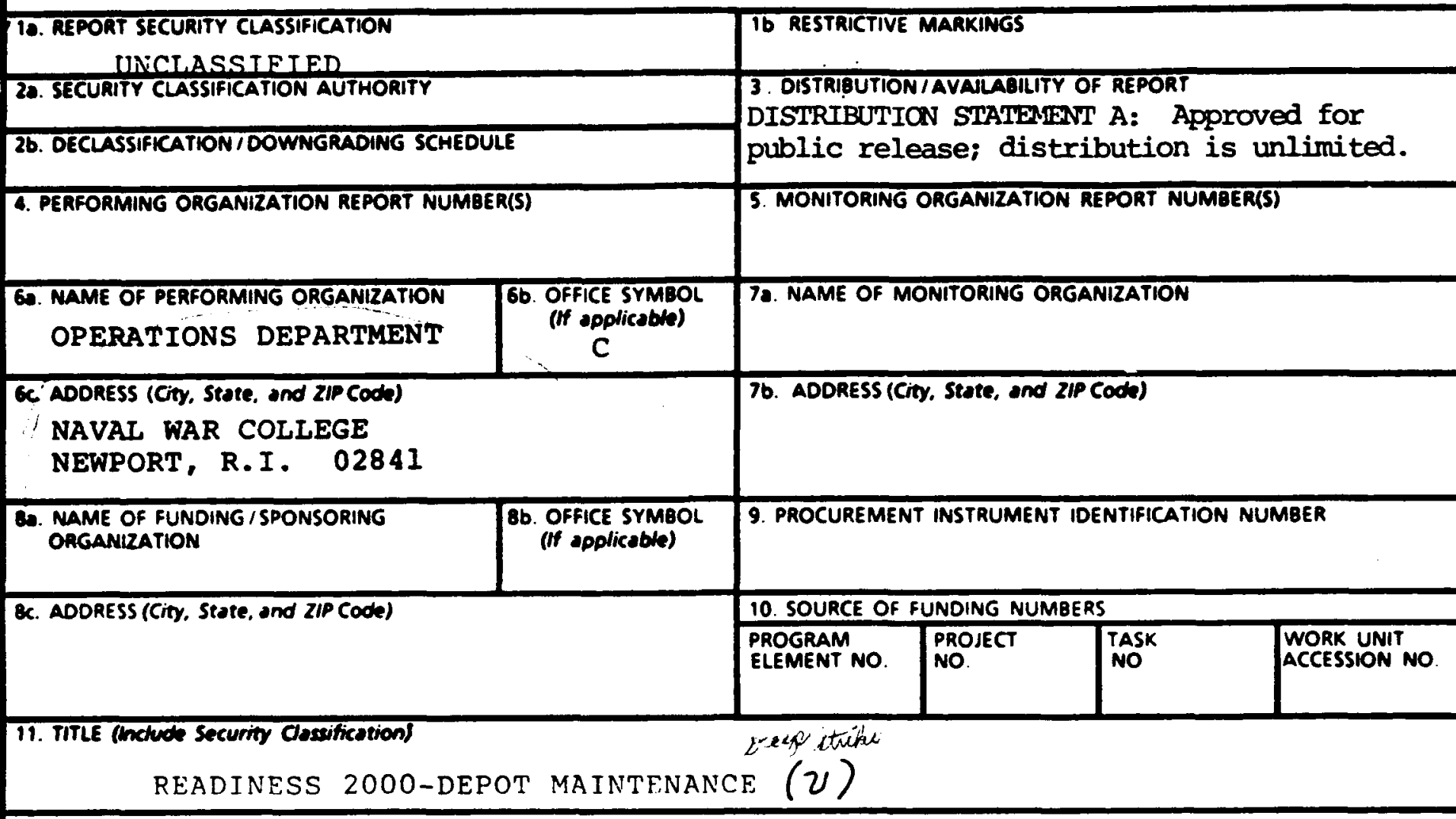

\begin{tabular}{l|l|l|l}
\hline 130. TYPE OF REPORT & 136. TIME COVERED & 14. DATE OF REPORT (YeOr, MONTh, DAY) & 15 PAGE COUNT \\
FINAL & FROM TO & 36 \\
\hline
\end{tabular}

16. SUPPLEMENTARY NOIATION A paper submitted to the Faculty of the Naval har College in partial satisfaction of the requirements of the Department of operations the conteits of this College or the Department of the Navy.

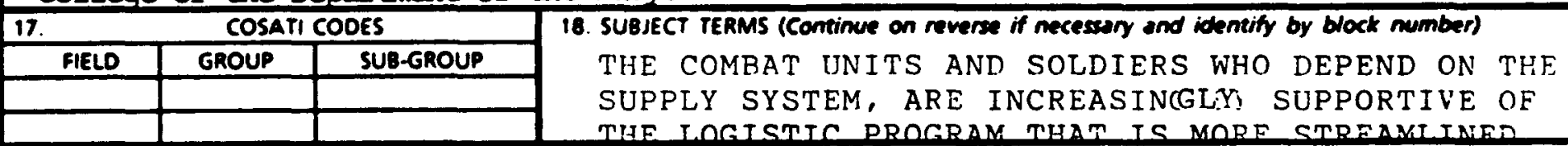

19. ABSTRACT (Continue on reverse if necessary and identify by block number)

THE ARMY'S STRATEGIC LOGISTIC PROGRAM IS AN UMERELLA CONCEPT DESIGNED TO ENHANCE THE COMMANDER'S ABILITY TO MAKE TIMELY TACTICAL/OPERATIONAL AND LOGISTIC MANAGEMENT DECISIONS AND TO IMPROVE THE RESPONSIVENESS OF LOGISTIC SUPPORT TO CUSTOMERS. IT IS A LONG-TERM INIIIATIVE, WITH NEAR AND MID-TERM GOALS DESIGNED TO DEFINE FUNCTIONAL LOGISTICS REQUIREMENTS FOR OPERATING THE ARMY LOGISTICS SYSTEM TO THE YEAR 2010 AND BEYOND. SLP INITIATIVES ARE FOCUSED ON IMPROVING THE CURRENT SYSTEMS AND ON DESIGNIN DEVELOPING, AND IMPLEMENTING PROCESSES THAT TRANSFORM THE PRESENT SEPAPATE RETAIL AND WHOLE SUPPLY SYSTEMS INTO A SINGLE. INTEGRATED NETHOR IN THE NEAR TERM, THE SLP CALLS FOR CONSOLIDATION AND INTEGRATION OF WHOLESALE AND RETAIL FUNCTIONS, INCLUDING EXECUTION OF EFFICIENCY ENHANCEMENTS MANDATED BY THE RECENT DEFENSE MANAGEMENT REPORT PROCESS. A MAJOR INITIATIVE INCLUDED IN THE SLP IS THE CONVERSION OF DEPOT-LEVEL

\begin{tabular}{l|l} 
20. DISTRIOUTION /AVAILABILITY OF ABSTRACT & 21. ABSTRACT SECURITY CLASSIFICATION
\end{tabular}

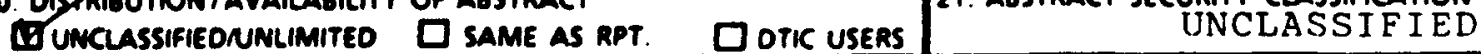

220. NAME OF RESPONSIBLE INDIVIDUAL CHAIRMAN, OPERATIONS

DO FORM 1473, 84 MAR

83 APR edition may be used until exhausted. All other editions are obsolete

22b. TELFPHONE (include Area Code) 22C. OFFICE SYMBOL

\section{DEPARTMENT

DEPARTMENT

SECURITY CLASSIFICATION OF THIS PAGE
0102-LF-014-6602 
REPARABLES - TO STOCK FUNDING. THIS PHASED EFFORT REDUCES A FUNDING LAYER, PASSES FULL COST FOR ITEMS ON TO CUSTOMERS, AND WILL BE FULLY! IMPLEMENTED IN 1992 THROUGHOUT THE DEPARTMENT OF DEFENSE. FOR LONG TERM, THE SLP FOCUSES ON A BROAD, COMPREHENSIVE ANALYSIS OF LOGISTIC REQUIREMENTS FOR THE YEAR 2000 AND BEYOND. FROM THIS ANALYSIS, THE ARMY WILL DEVELOP FUNCTIONAL STATEMENTS FOR ITS FUTURE LOGISTIC SYSTEM. 
CHAPTER

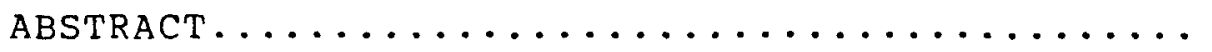

I I CENTRAL SUPPLY PROGRAM.............

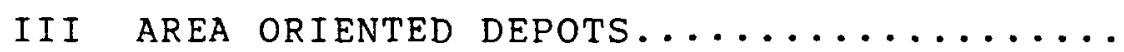

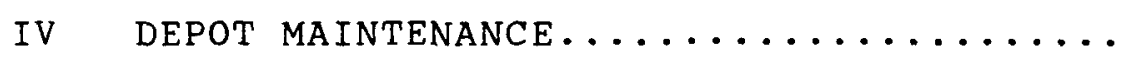

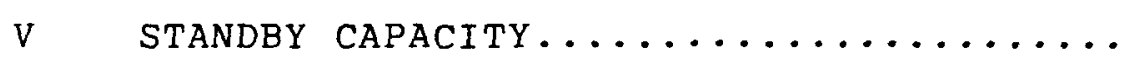

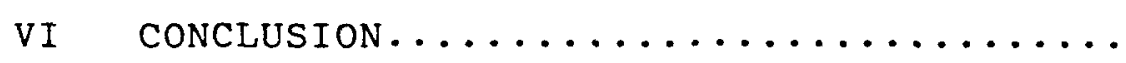

BIBLIOGRAPHY ........................

LIST OF ILLUSTRATIONS (BRIEFING)...........
PAGE

2

4

6

9

14

18

20

21

22 
Abstract of

Readiness 2000 - Depot Maintenance

DEEP STRIKE

The Army's Strategic Logistic Program (SLP) is an umbrella concept designed to enhance the commander's ability to make timely tactical/operational and logistic management decisions and to improve the responsiveness of logistic support to customers. It is a long-term initiative, with near and mid-term goals designed to define functional logistics requirements for operating the Army logistics system to the year 2010 and beyond. SLP initiatives are focused on improving the current systems and on designing, developing, and implementing processes that transform the present separate retail and whole supply systems into a single integrated network.

In the near term, the SLP calls for consolidation and integration of wholesale and retail functions, including execution of efficiency enhancements mandated by the recent Defense Management Report (DMR) process. A major initiative included in the SLP is the conversion of depot-level reparables to stock funding. This phased effort reduces a funding layer, passes full cost for items on to customers, and will be fully implemented in 1992 throughout the Department of Defense. 
3

For long-term, the SLP focuses on a broad, comprehensive analysis of logistic requirements for the year 2000 and beyond. From this analysis, the Army will develop functional statements for its future logistics system. 


\section{READINESS 2000-DEPOT MAINTENANCE}

\section{DEEP STRIKE}

CHAPTER I

\section{INTRODUCTION}

The Defense maintenance depot system is made up of 33 major industrial facilities located in the United States and overseas. The depot system is arranged among the services as follow; Army - 10, Navy - 17, Marine Corps - 2 and the Air Force - 10. Each service is responsible for managing its own depot maintenance activity. In addition several depot maintenance services are contracted with the private sector in Conus and overseas industrial. Most of the depot maintenance facilities were constructed during World War II when the nation was called to full mobilization. The services have been under public and congressional pressure to reduce the number of depots to avoid excess capacity and waste while investing in modernization to ensure that depots provide responsive support to the services. The current depot maintenance budget is about $\$ 12$ billion per year. The services are also being pressured by high cost; budget reduction and Congress to increase apportionment of the work load to the sector and overseas sources.

The issue is whether services are capable of eliminating excess capability; and duplication of repair capability 
and maintain force readiness. This research paper will

describe those initiatives that the Army is proceding to address: readiness; sustainability; and support of the Army through its depot system maintenance program.

The combat units and soldiers who depend on the supply system, are increasingly supportive of this logistics program that is more streamlined than ever before. 
CHAPTER II

CENTRAL SUPPLY PROGRAM

The largest portion of the central supply program is supply depot operations which funds the receipt and issue of materiel, physical inventory, rewarehousing, and care of supplies in storage (COSIS). Supply support functions will continue to be accomplished at a minimum acceptable level. Minimum stockages levels are determined by denmand history data reflecting items usage. The supply depots system will be funded through reimbursement from the Army stock fund. Since the salaries of most supply depot personnel will be dependent on sales to the retail customer the ability to accurately forecast workload and operate an efficient depot supply system will become extremely important. While depot operations are the largest resource consumer, the materiel management tasks - computing requirements, procuring and distribution, are the heart of the operation.

The Army has experienced in the last five years in executing its spares program in support of equipment readiness. In FY90, they will execute 97 percent of the approved procurement appropriated spares program dollars. While this is good news, a number of action have served to reduce overall program dollars. The FY90 approved program is 21 percent less than the Army's budget request. This is a result of an initial $\$ 60 \mathrm{M}$ unfunded bill, additional Gramm-Rudman-Hollings reductions, and 
Congressional decisions.

Funding for the proposed Fy91 stock fund program represents the fourth consecutive year of underfunding. Demands in FY88, 89, and 90 have exceeded the annual authority. The result is stock reduction and lower availability of mission-essential components in FY92 and FY93, and reduced equipment readiness. However, the impact or effect will not be known until force structure stabilizes. The Army's FY90 stock fund was similarly affected and resulted in budget reductions totaling $\$ 454 \mathrm{M}$, or 29 percent of the requested funds. While significant funding reductions have been levied on many programs, the Army has taken steps to ensure available dollars are applied to critical items during execution of the program.

The Army has taken action to draw down spare and repair parts inventory needs for FY90 and beyond consistent with planned force structure reductions. The commodity commands have instituted procedures to recompute safety level requirements on an item-by-item basis to ensure that depot repair and procurement actions effectively support essential spare and repair parts requirements.

While the depots performance analysis system currently operates in a peacetime environment, wartime achievements can be seen in the Army's support to operation "Just Cause." During the operation, the depots performed all actions required to provide full supply support to our forces. 
Critical items were tracked from depots through air terminals to Panama, including the Defense Logistic Agency and General Supply Agency managed items. If the troops in Panama had a requirement, the Army community found it and shipped it. Items not currently in stock at depots, were located in non-deploying units and directed for shipment to Panama. During operation "Just Cause", the depots processed 2,054 requisitions for a quantity of 242,751 items of equipment, ammunition and spare parts. The Army depots filled $\$ 7$ percent of the material requested. 
CHAPTER III

AREA ORIENTED DEPOTS

The distribution of supplies to our soldiers is provided primarily through area oriented depots. The Army's program to modernize its area oriented depots with state-of-the-art distribution centers was initiated in May 1981 with the approval of the design effort for the western distribution center at the Army's depot located on the west coast. The area oriented depot modernization program will provide the Army with distribution facilities capable of sustaining a high level of support to the modern Army well into the next century. The Army has a second facility located in Pennsylvania. The planned efficiency of these two depots and force structure drawdown allowed the Army to reconsider a planned third facility. This decision was based on actual workload generation and pending force reductions which creates less favorable savings to investment ratio. The two distribution center facilities will boost efficiency and productivity, and will significantly improve the Army's ability to provide reliable, responsive support to the soldiers.

Another state-of-the-art project the Army is undertaking, is a logistics system modernization plan. The Strategic Logistics Program (SLP) will provide the Army with a logistic system that includes the principal logistics 
functions and provide maximum weapons systems support by improving parts availability. Another major objective is to reduce the logistics pipeline investment and leadtime. A subset of SLP, is the objective supply system (OSS). Through oss the Army is developing a process to achieve interactive, near real time processing of requisitions and to significantly reduce the amount of required to fill customer requests for supplies. Under oss, the order ship-time (OST) required to fill a request has been reduced from 12-25 days to 5-10 days. The operational prototype is scheduled to be on 1 ine at units in Texas and Alabama in early 1991.

The Army's role in supporting the soldier is also reflected in its use of assets in the hands of the troops. The European redistribution facilities (ERF), continue to be a great success in redistribution of theater assets. Acting as a retrograje processing facility, the ERF sites have been most valuable in expediting and managing the return of unserviceable depot level reparables.

The Army's committed to spending constrained resource wisely, through an aggressive program to improve competition performance. It was this efforts that improved competition performance that reduced the price of goods and services procured in FY89 an estimated $\$ 368 \mathrm{M}$.

The Army's most significant challenges in the supply area is disposition of excess. It's first objective is to reduce the 
creation of excess materiel. The Army has taken a number of action both in the field and in the commodity commands to achieve this objective. One of the Army's most promising initiatives is the Objective supply system. This system provides greater visibility of supplies and more field confidence in the logistic system, allowing for reduced stockage level. Two major influences on reducing the creation of excess are provisioning and the requirements determination process, both of which are being modified.

The Army's second objective is to dispose of excess materiel. During the past years, significant progress has occurred in reducing the levels of unserviceable and inapplicable inventory in the depots. Contributing to this increase are the conservative retention policies developed after the "Disposal Freeze" in 1985-86. These stocks were unnecessarily tying up inventory investment and had begun to cause serious overcrowding, adversely impacting depots operations. In an effort to relieve the depots of overcrowding conditions, consistent with existing retention policies, the Army took action to dispose of inapplicable inventory. Disposals from the depots, as of the end of 1989 had increased by over 177 percent (from $\$ 279.1 \mathrm{M}$ in 1988 , to $\$ 772.1 M$ in 1989). The Defense Management Review (DMR), part of which authorized elimination of numeric retention stock, Will provide further relief from inventory investment and 
overcrowding in the depots. This put the Army in a better position to receive and store equipment returned to the depots as result of force reductions and base closures.

The downsizing of Army units presents a challenge to the Army's supply system in its efforts to utilize its assets in the most effective and efficient way. The Department of the Army is emphasizing redistribution of systems, equipment and supplies to units with outdated systems or shortages. Second priority is fill of POMCUS, war reserve, other services requirements and security assistance prior to initiating any action to dispose of excess assets.

Defense Management Review initiatives will impact the Army's supply system in the coming years by integrating the wholesale and retail logistics systems into one system. This initiative centers on total asset visibility and weapon system orientation. Using the concepts described in the objective supply system, together with visibility of stocks at all echelons, the Army will buy items needed to replace losses and maintain optimum inventories. The objective is also to maximize availability of the weapons systems by judicious repair and distribution decisions. The Army logistic system will target on the most pressing needs for keeping weapons systems in operation through the use of repair and distribution capability. This responsive capability is not only economically attractive but gives the 
services an edge in contingency situations. The plan is to modify the logistic information system in the field, in the depots and in the inventory control points so that real time assets data is available to decision makers.

The other initiative impacts the funding appropriation for spares. This will transition all depots level reparables (DLR) currently procurement appropriation funded, into the Army stock fund. At that time the Army will begin financing many depot and subordinate command supply support functions through stock fund. Currently these are funded from O\&MA. While the result will be to place greater financial responsibility on the wholesale level as well as on individual field units, stock funding reparables will provide the Army with more control over inventories and the dollars savings associated with that control. This will translate into fewer buy actions and more reliance on repair. 
CHAPTER IV

\section{DEPOT MAINTENANCE}

One of the major components in equipping and sustaining the force is depot maintenance. Depot maintenance requirements are resourced at $\$ 1.8 \mathrm{~B}$ in FY90 and $\$ 1.5 \mathrm{~B}$ in $F Y$ 91. For both years approximately 60 percent of the maintenance workload will be accomplished by dedicated supply personnel. Depot maintenance consists of overhaul, repair, and renovation of major end items and secondary components

In FY89, the depots accomplished overhaul and repair of 477,072 items; 31,164 major and 445,908 secondary items. These items include aircraft, tanks, engines, and small arms. The Army tested organic depot capability to react to production surge demands by tasking depots to radically increase production of items which were in short supply. Production for three high demand tank and automotive items was successfully tripled on short notice. Critically essential aviation items was successfully increased with little notice. In both case, the Army's ability to react to increase production requirements was made possible by a strongly committed workforce and in-depth job knowledge. Surges like these affect an entire depot workforce. These surges would not be possible without an overall commitment to teamwork. Both surges tested the flexibility and 
responsiveness of the depot, demonstrated capacity support to support mobilization, and increase depot maintenance production output for critical repair parts. The Army must retain this capability and continue to obtain the machinery and training necessary to repair equipment which uses developing state-of-the-art technology.

As newer weapon systems exploit the advances in sophisticated electronics and composite materials, investment must be made in the depot's capital equipment so we can support the soldiers's weapons. This is especially important for low density systems because of manufacturing cost. The depots historically provide, and must continue to provide the support for these systems regardless of quantity. The Army is attacking the challenge of reduced resources by making the depots more efficient. The Army has developed a consolidated maintenance facility. This program will combine the supply, maintenance, and shipping functions required for several types of trucks, trailers, generators and other equipment into one well organized building. This will replace dozens of smaller buildings which were less efficient. The final result will be improved capacity and greatly improved efficiency.

As part of the Defense Management Review process, the Army is developing plans to consolidate depot maintenance workloads aimed at achieving greater economies and 
efficiencies. These consolidations involve both internal redistribution of work and increase interservicing of items which are common to more than one service. The consolidations that are being considered are targeted to increase the capacity utilization of service depots and eliminate duplicate capabilities in DOD facilities. The consolidation which appears to offer the best payback on investment is communications and electronic items. The pace and method by which these consolidations will proceed considers the readiness needs of the services as well as the separate prerogative to control individual sustainment needs. The general downsizing of the depot maintenance operation coupled with these consolidations will produce increased capacity utilization of facilities and lower expense rate tied to direct labor hours.

As a result of the recommendations in the base realignment and closure report, the Army has begun to consolidate many of its communication and electronic depot overhaul functions at it's depots.

Realignment of depots will provide economies on scale from the consolidations. Flexible manufacturing at depots will allow the Army to manufacture and fabricate parts which cannot be obtained from industry such as the night vision adaptors. This will result in a tremendous cost saving. As part of base realignment and closure and DMR initiatives, 
17

the Army has begun further consolidation efforts. This overall process has significantly improved the availability of modern, accurate and reliable equipment for all the services. 
CHAPTER V

\section{STANDBY DEPOT MAINTENANCE CAPACITY}

Standby capacity is an important reason for the existence of the Army's depots. In the event of mobilization, the depots are the primary source for maintenance support until industry is able to meet the military needs. Having sufficient maintenance capability and capacity means retaining an adequate skill base for maintaining equipment, and providing a baseline level we would use to expand to meet mobilization needs. Budget constraints will reduce our capability, but we expect to retain our expertise. The Army is examining ways to fund mobilization requirements, specifically, we should not charge mobilization requirements to on-going depot programs.

The Army must continue to effectively balance peacetime workload to ensure an optimum state of material readiness and sustainability while obtaining the most effective and efficient use of resources.

Renovation of Army depots for the year 2000 will modernize supply and maintenance depots to keep pace with technology and new workloads. Budget constraints over the years have limited the Army's capability to modernize depots throughout the Army. The Army will continue to develop and improve the effectiveness of its depots with innovative ideas and approaches in modernization. Coupled with this modernization 
process, depots could be streamined through the use of commercial maintenance practices of functionally similar commodities. These practices could replace the detailed performance specification and reduce costs significantly.

The Army is faced with many challenges as aged and outdated facilities in the service continue to have detrimental impacts across all facets of our logistic and materiel support system. The Army will continue to scrutinize how it will perform its depot maintenance mission and seek ways to improve. 
CHAPTER VI

CONCLUSIONS

Logistics support doctrine is being changed to meet the needs of a modern fighting force. The Strategic Logistic Program will streamline and modernize the Army's logistic into the twenty-first century. When completed, the program will eliminate the distinction between wholesale and retail; that is the soldier who is dealing directly with the customer at the unit level will have access to and knowledge of the same data available to the item manager at the depot level.

The integration will enhance 21 separate supply, maintenance, transportation and distribution management programs through process enhancement to reduce order shipping time; establish a single stock fund; base provisioning on real-time data base input; improve materiel returns; eliminate excess stock; and reduce stock fund depot-level reparables and certain others repair parts.

The overall logistic architecture gives the Army the ability to intergrate across the tactical battlefield, vertically and horizontally, in the logistic disciplines of supply; maintenance; property accountability; ammunition; and transportation.

Modernizing and streamlining the Army's logistic operation are critical to increasing readiness and efficiency of operations, and that is why the Strategic Logistic Program will play a vital role. 
BIBLIOGRAPHY

1. von Clausewitz, Carl. Vom Kriege ON WAR, (16th edition), Bonn, Dummlers Verlag, 1952.

2. Dean, David J., Low-Intensity Conflict and Modern Technology, (forward by Newt Gingrich), Air University Press, Maxwell AFB, Alabama, 1968 .

3. Dunn, Keith A., Alternative Military Strategies for the Future, Westview Press, Boulder/London, 1985.

4. Heskett, James L., Business Logistics, Ronald Press Company, New York, 1973.

5. Mao Tse Tung and Che Guevara, Guerrilla Warfare, (trans. Griffith, forward by Liddell Hart), London, Cassel1, 1987.

6. Simpkin, Richard E., Deep Battle, The Brainchild of Marshal Tukhachevsk11, Brassey's Defense Publishers, London, 1987.

7. Thibault, George F., Dimensions of Military Strategy, National Defense University, Washington D.C., 1987.

8. U.S. Dept. of Defense, Report on Department of Defense Spare Parts Management Washington: 1990 .

9. U.S. Dept. of Defense, Maintenance Depot Consolidation Study Washington: 1990 . 
LIST OF ILLUSTRATIONS

BRIEF ING 

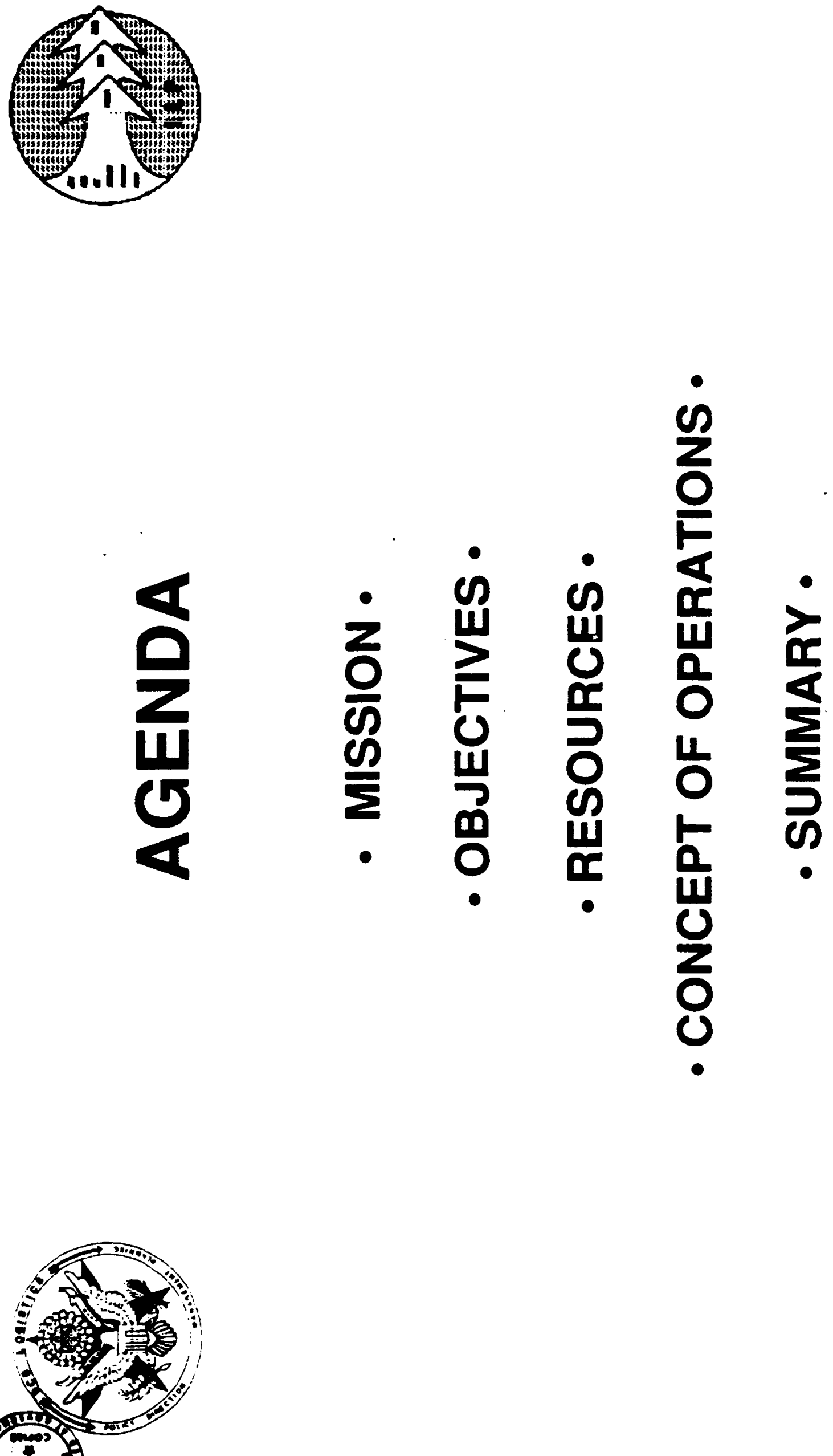


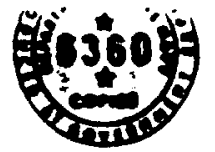
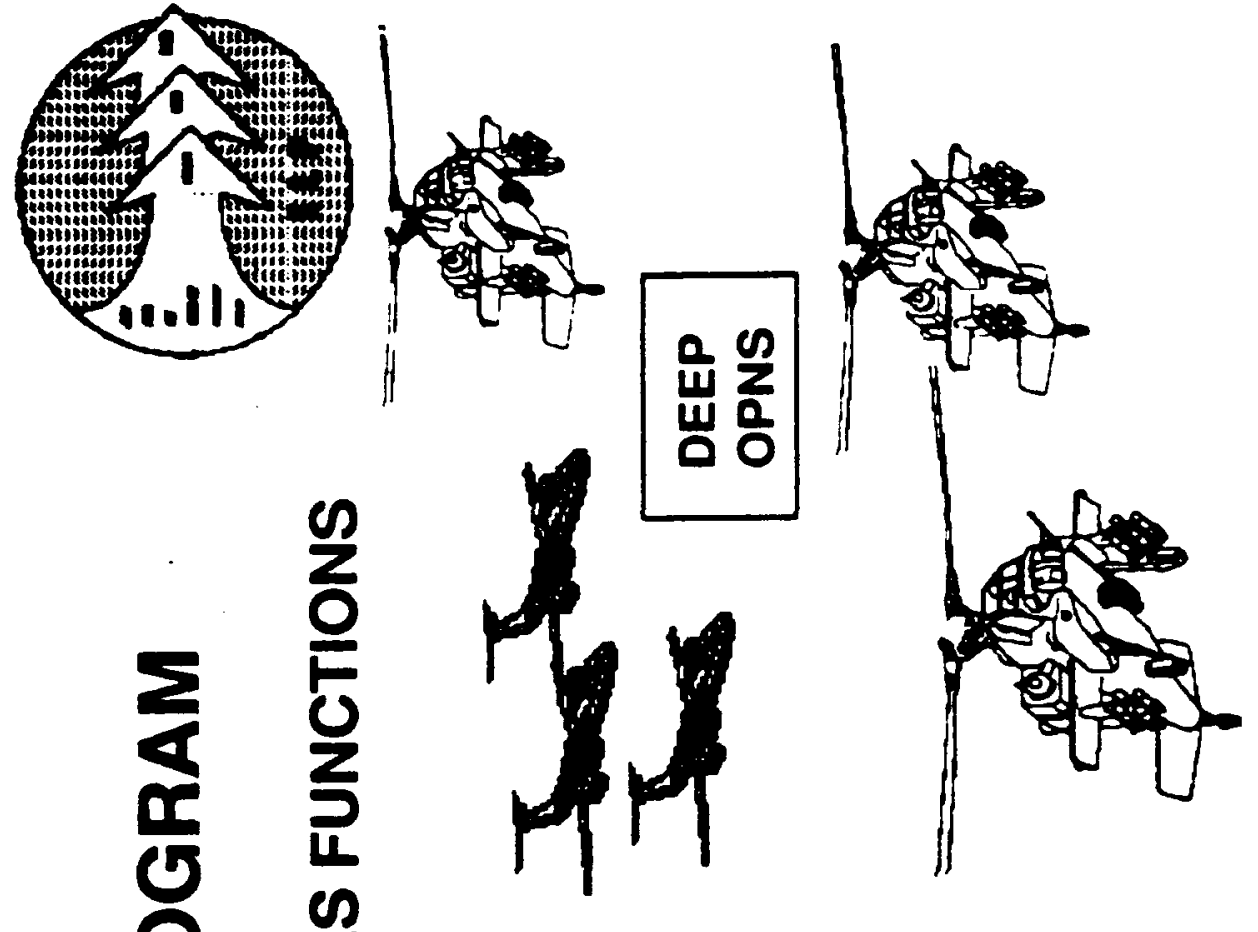

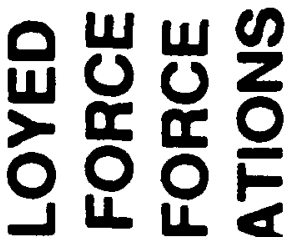

잉

யั่ง

느응

¿

$420 \div$

$3 E \frac{1}{2}$

다에

웜ำ

0 是

D

ㄴ 4 का

c EU⿺𠃊丶万

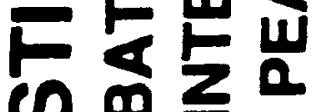

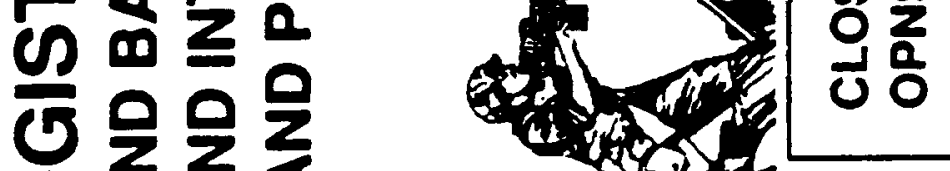

wis

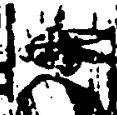

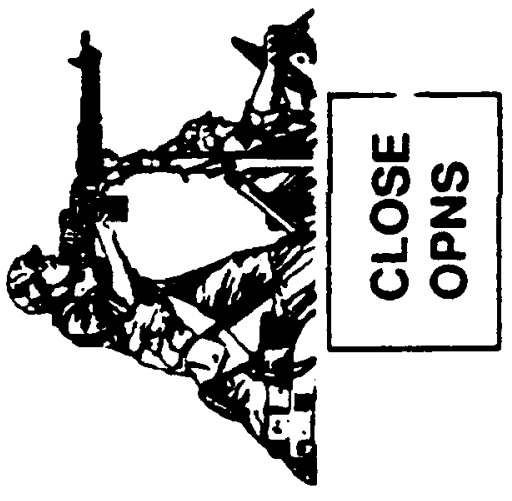

tudento

re- 4

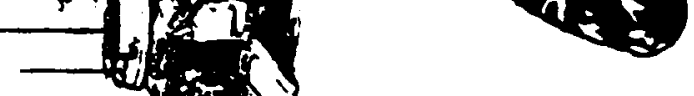

$0<\leqslant<$

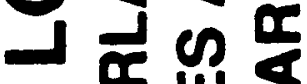

0 는

(ง)

U11

- 0 늠

$-2 \frac{1}{2}$

도웅

क क क
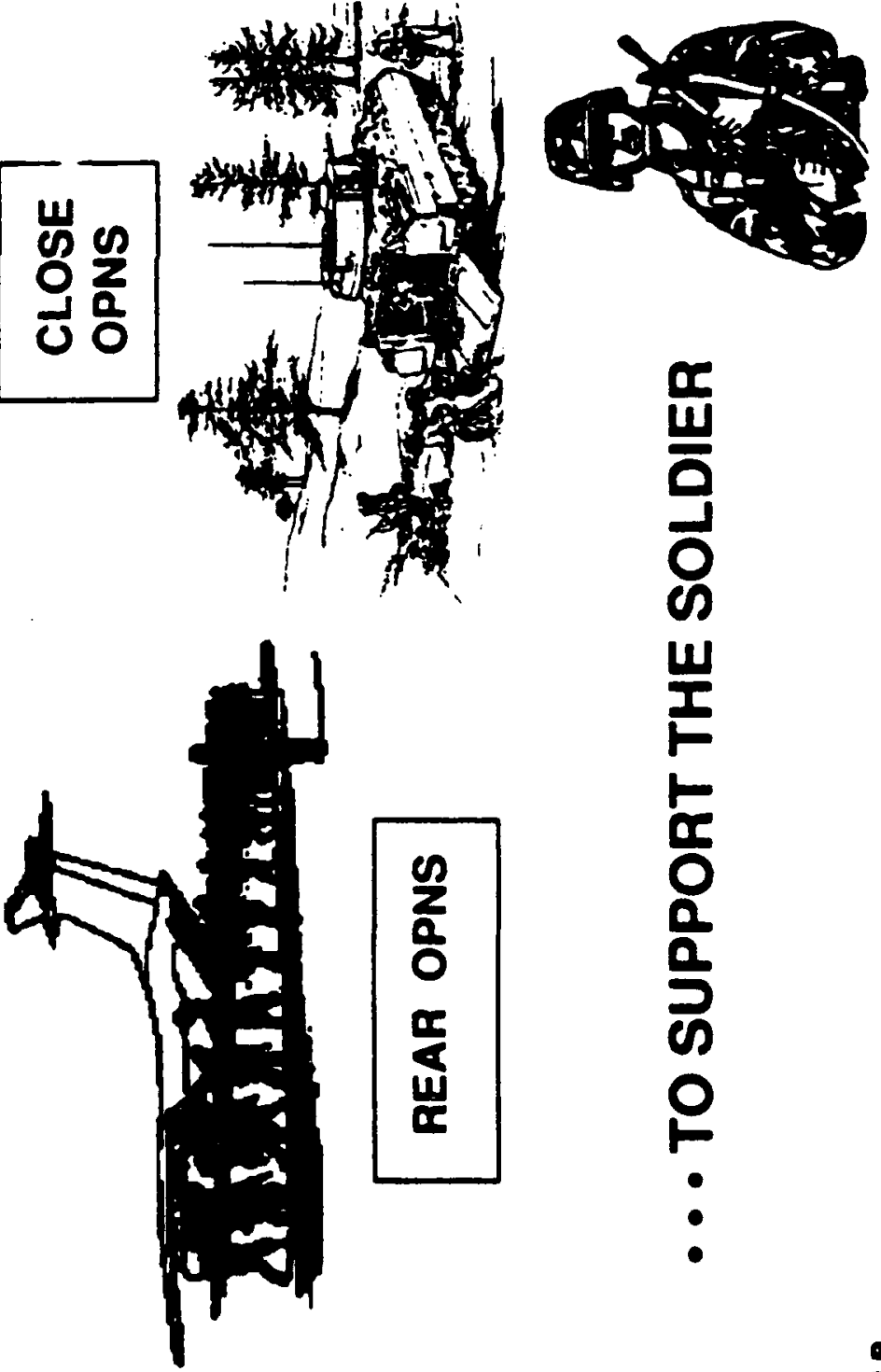

$\frac{0}{0}$

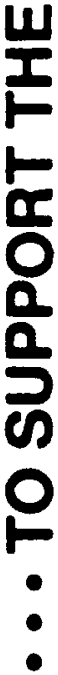

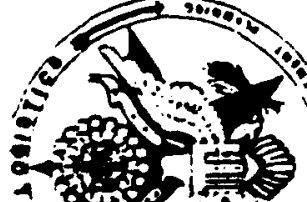




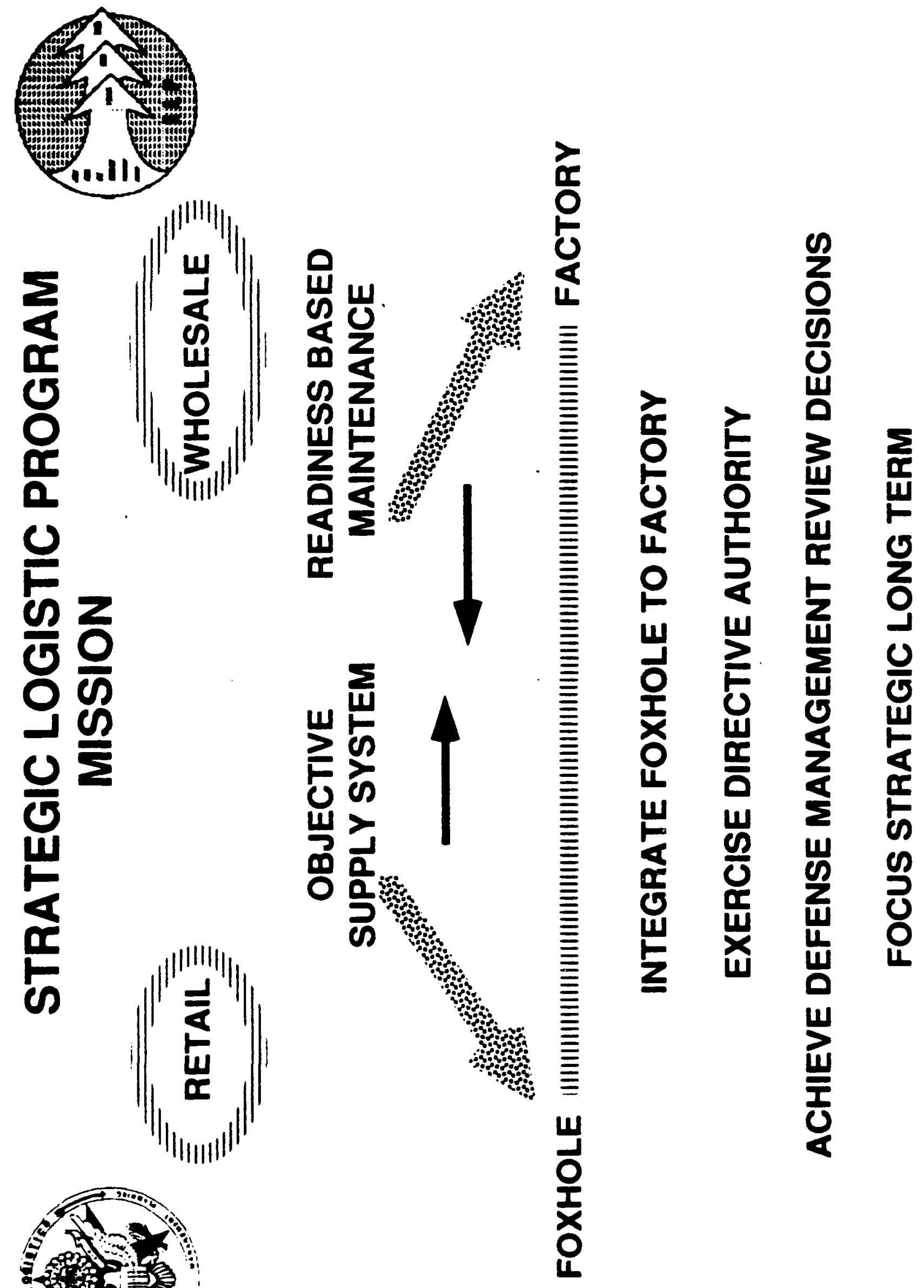




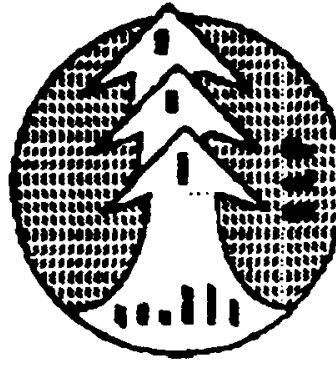

$\frac{u}{0}$

19

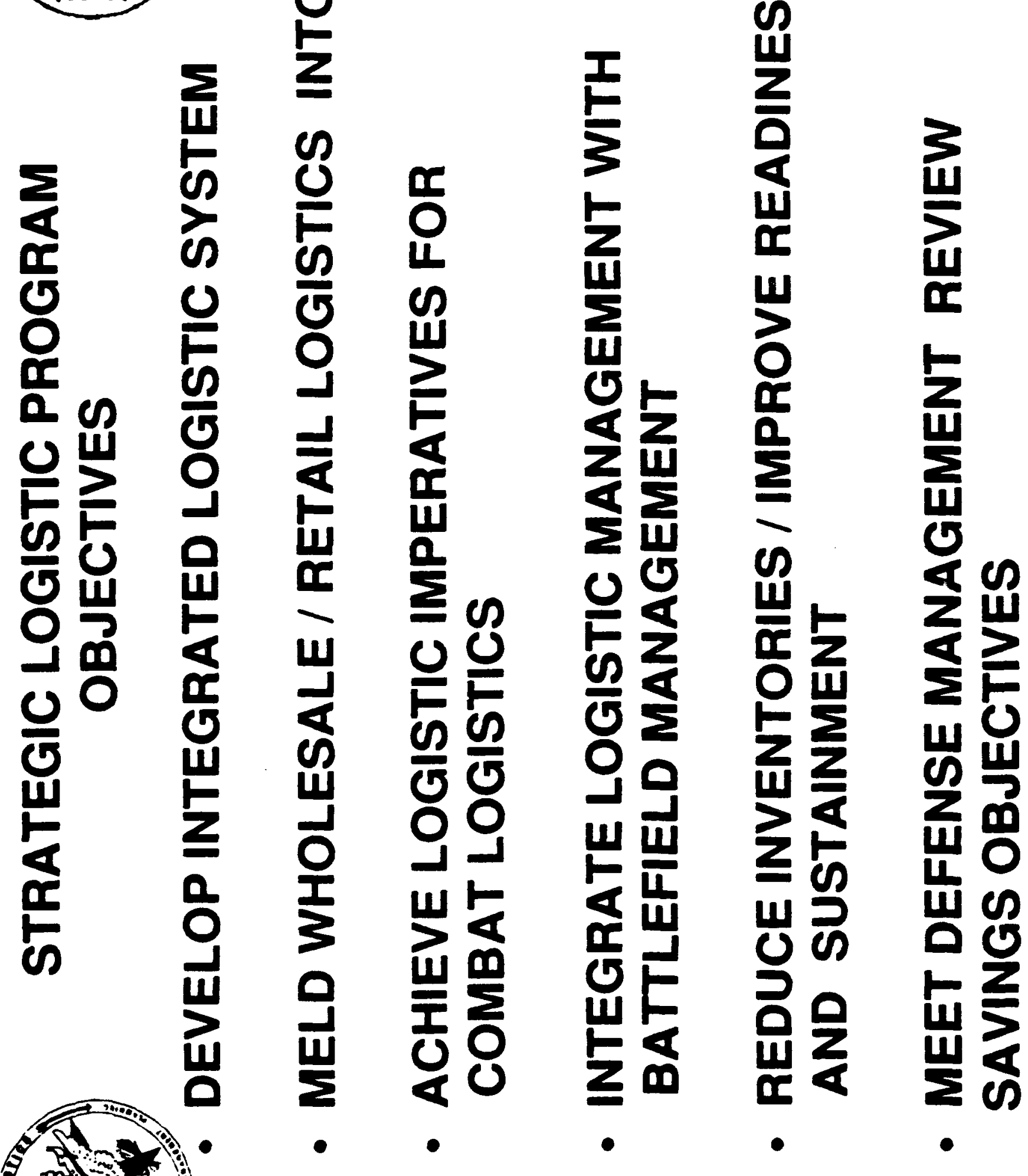



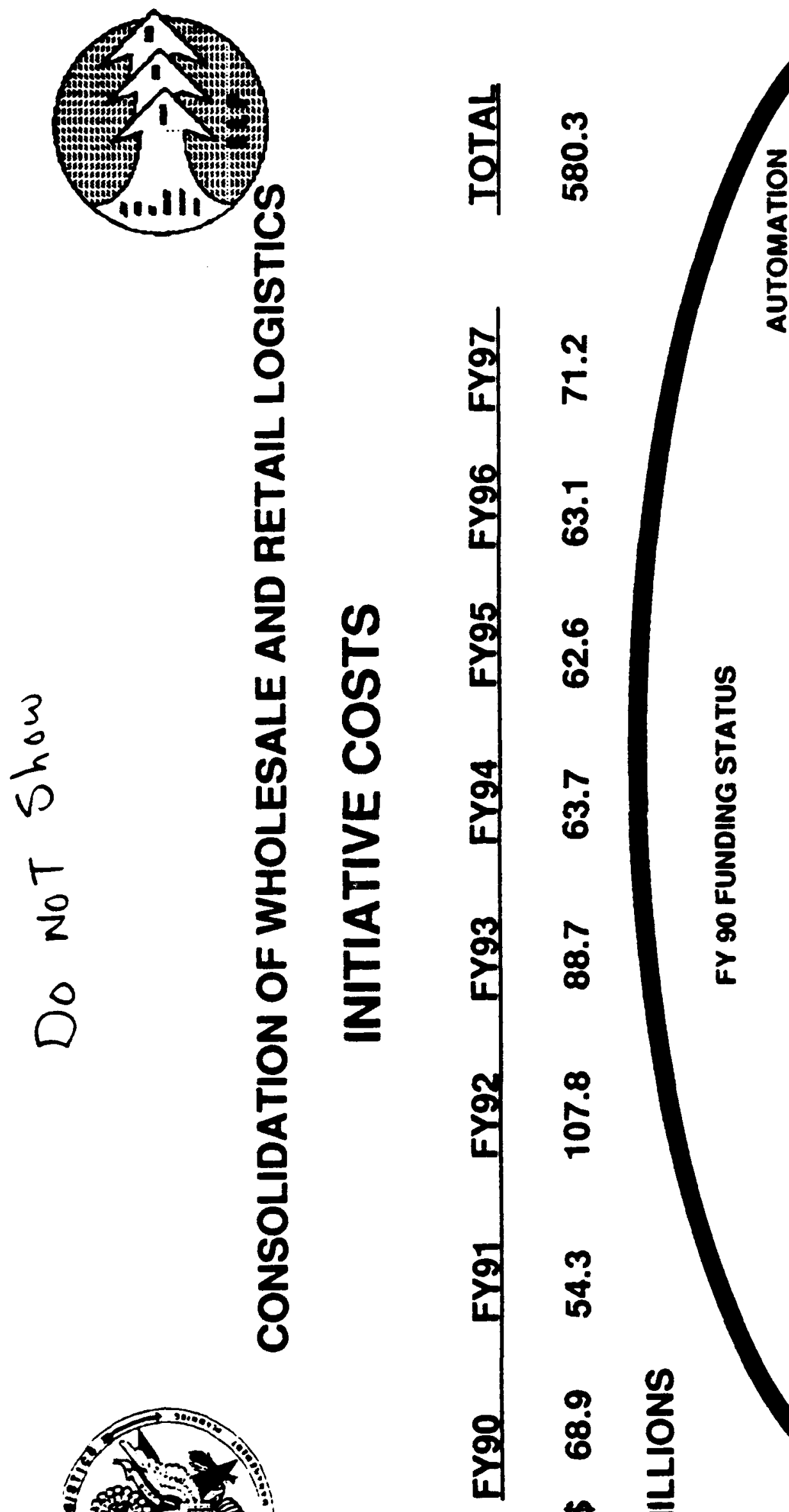

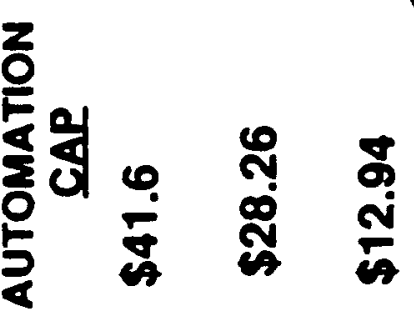

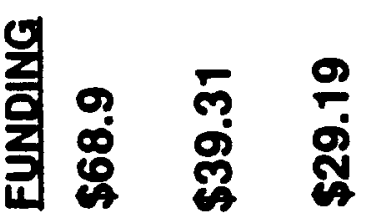

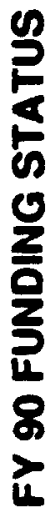
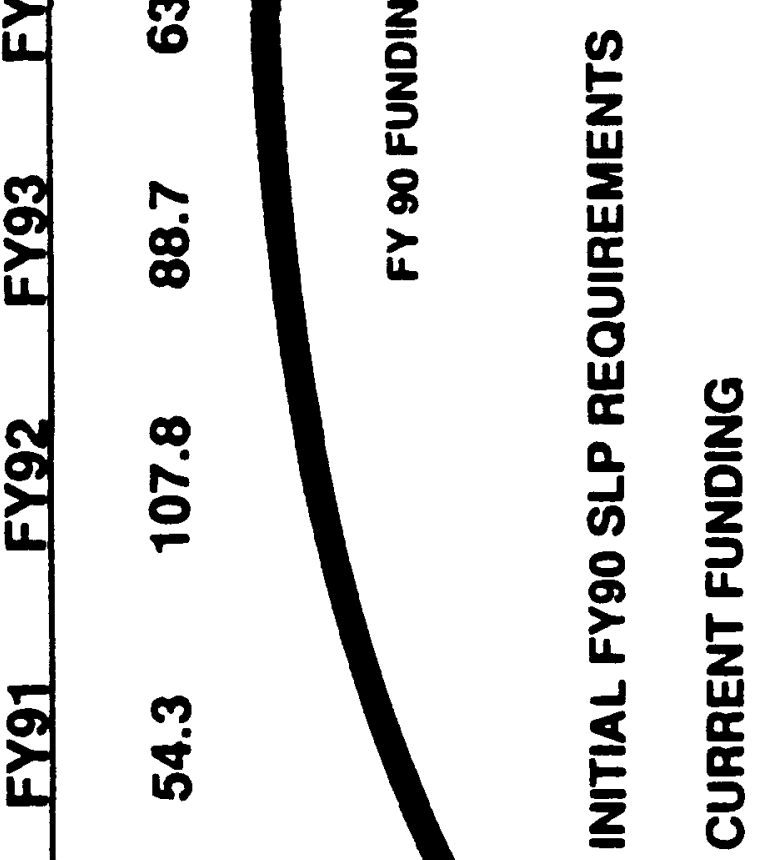

$\frac{1}{2}$

$\infty$

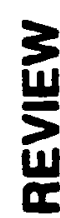

i.

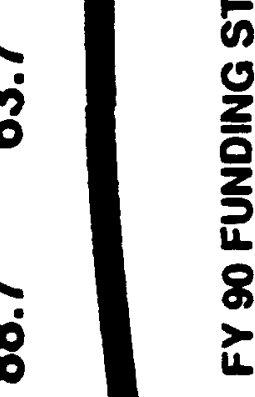

i

II

2

0

준

6

픔

के 

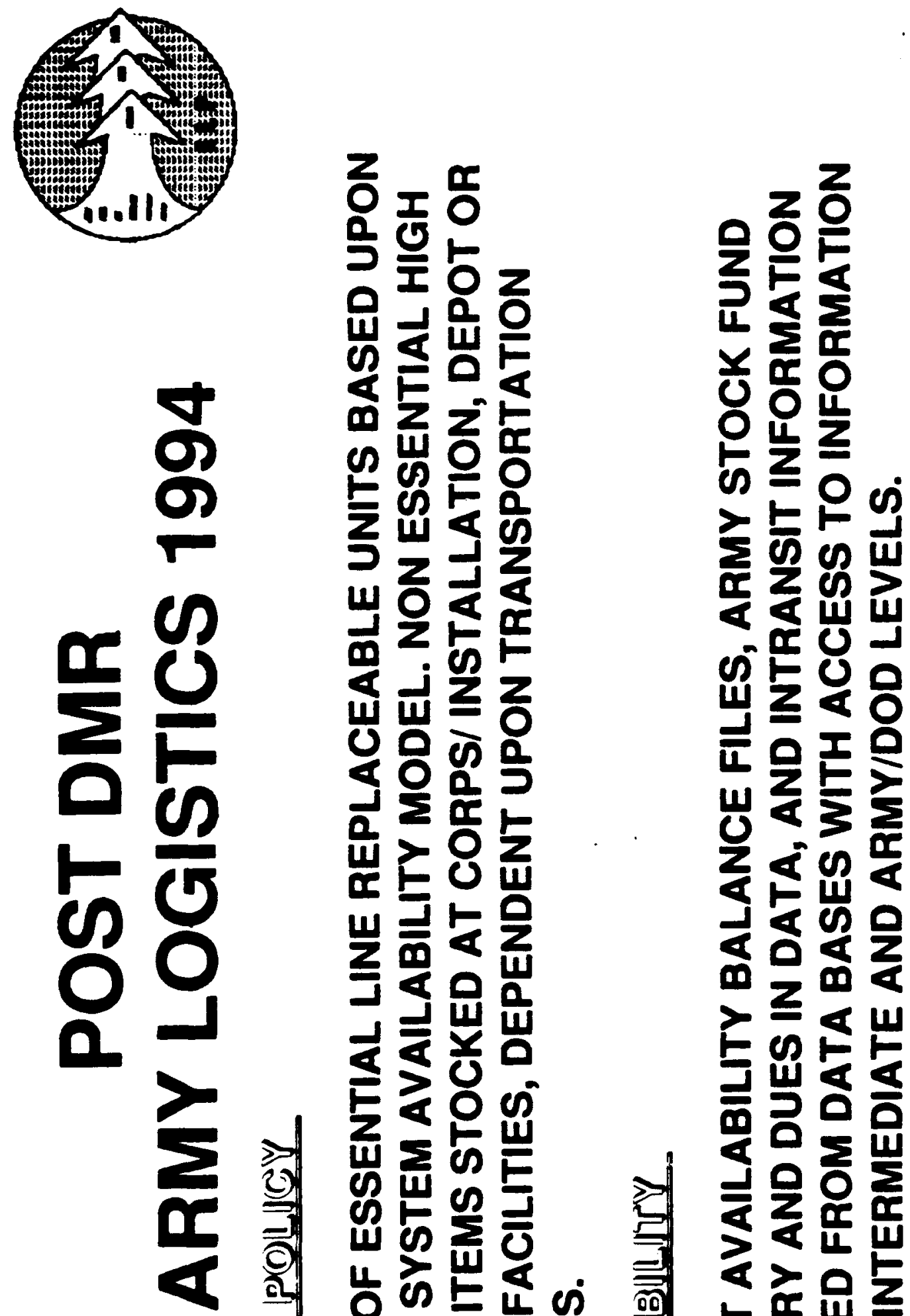

(6360)

I 


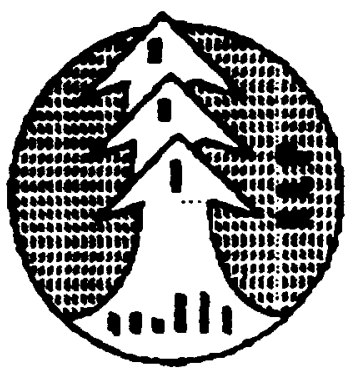

Exima

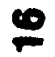
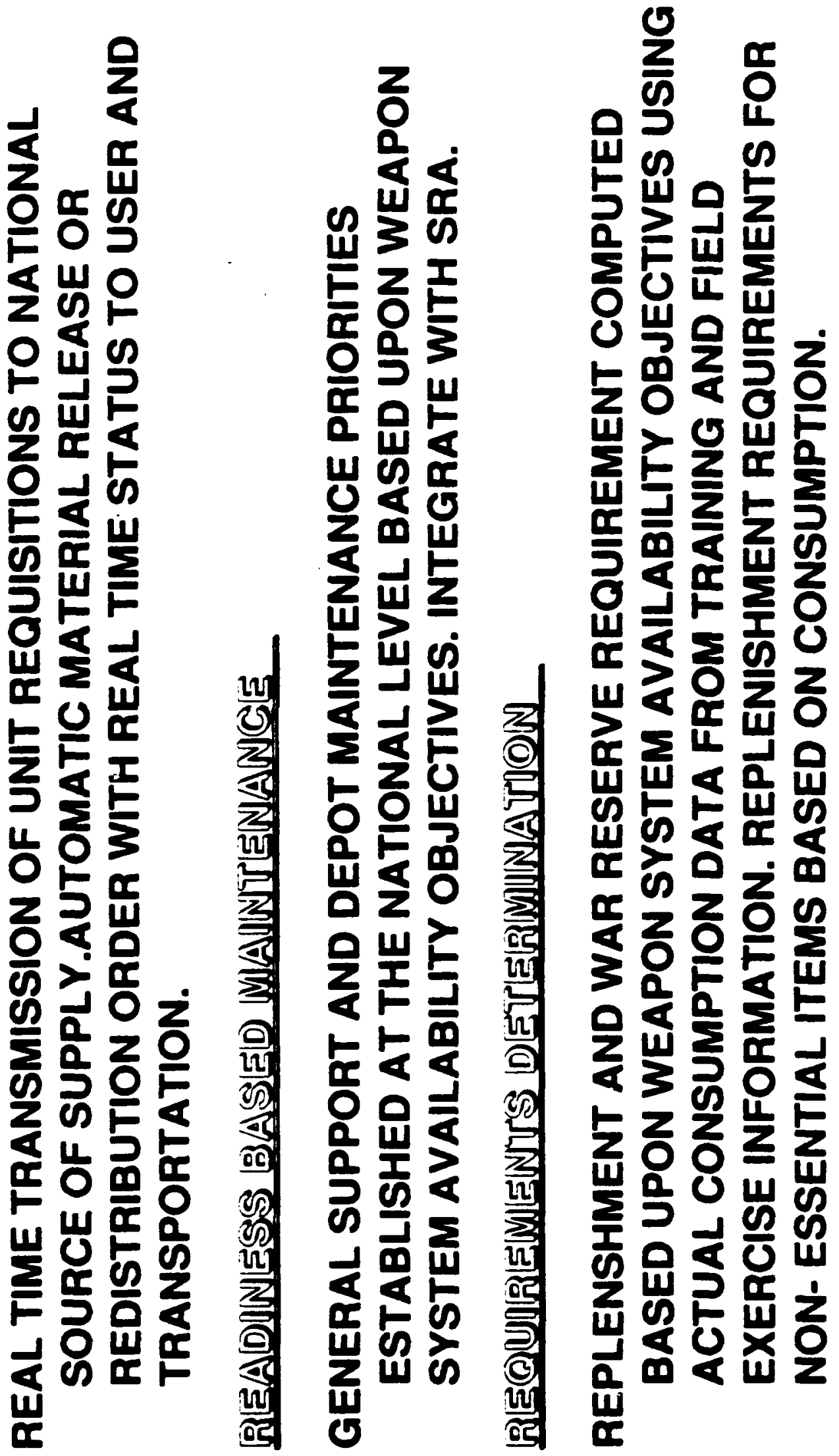

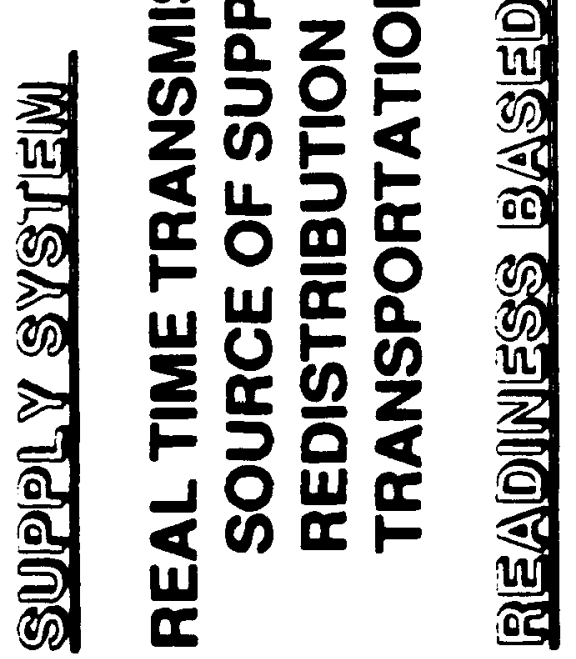

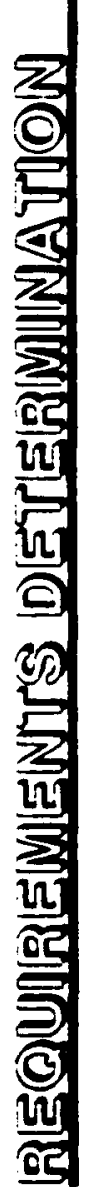

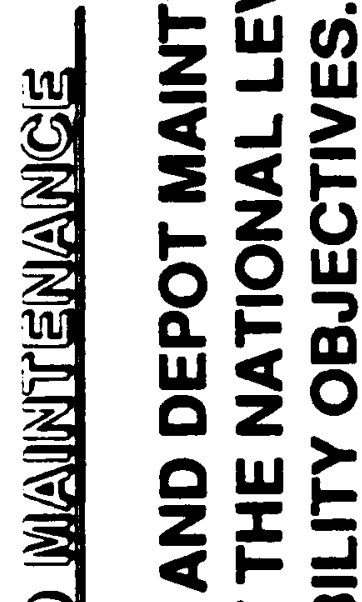

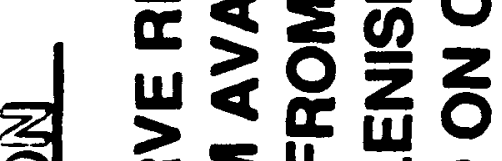

C)

02

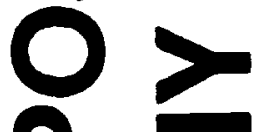

02

ac

4

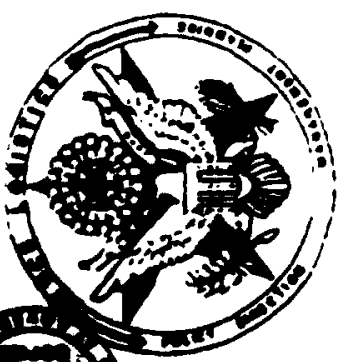




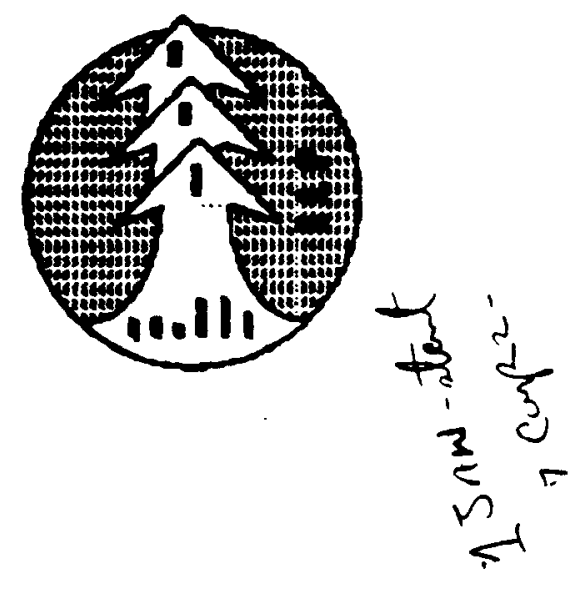

(6)

\&
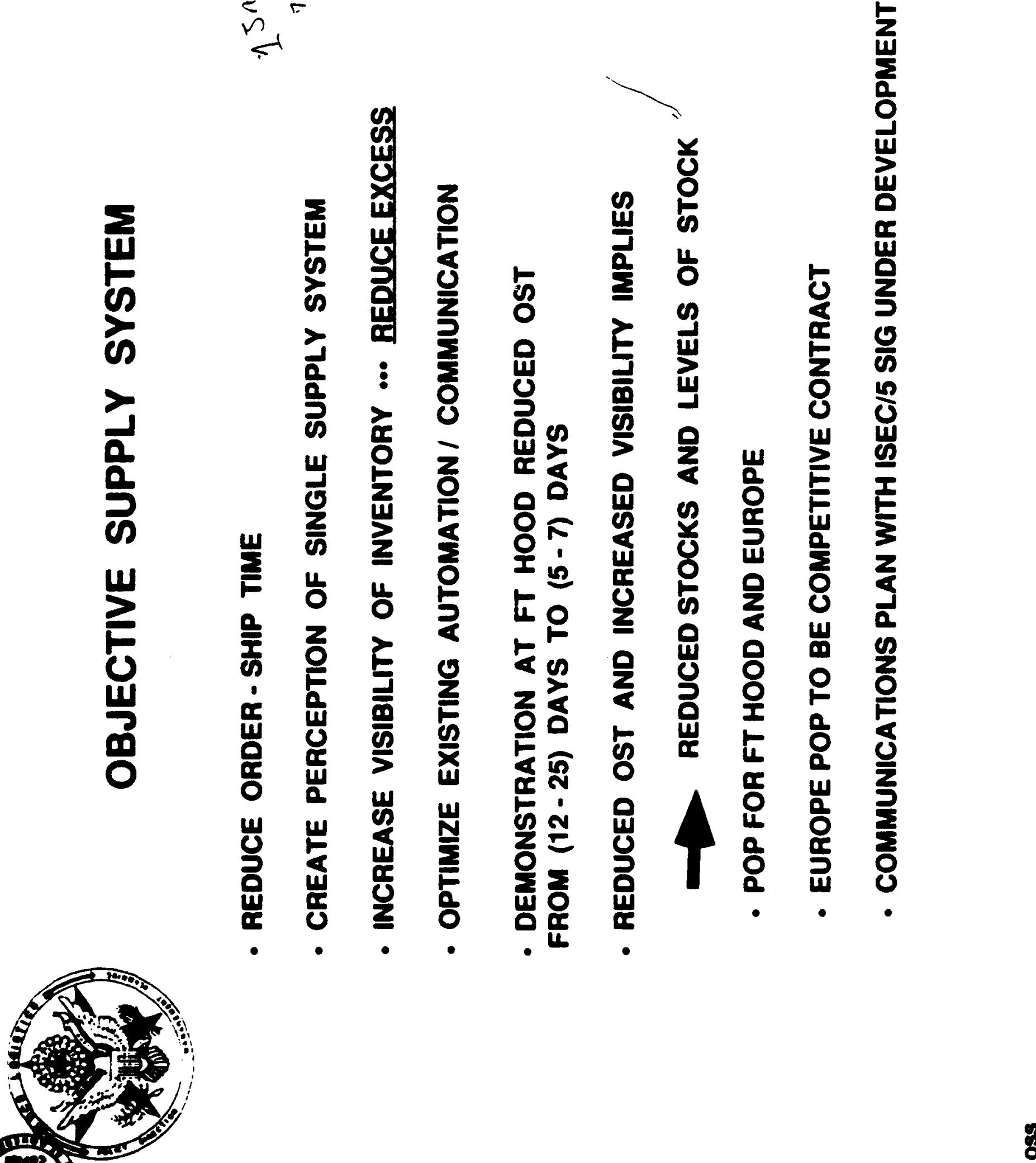


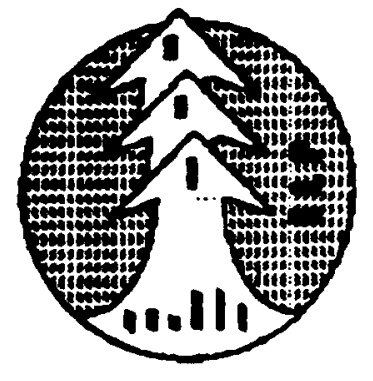

कू
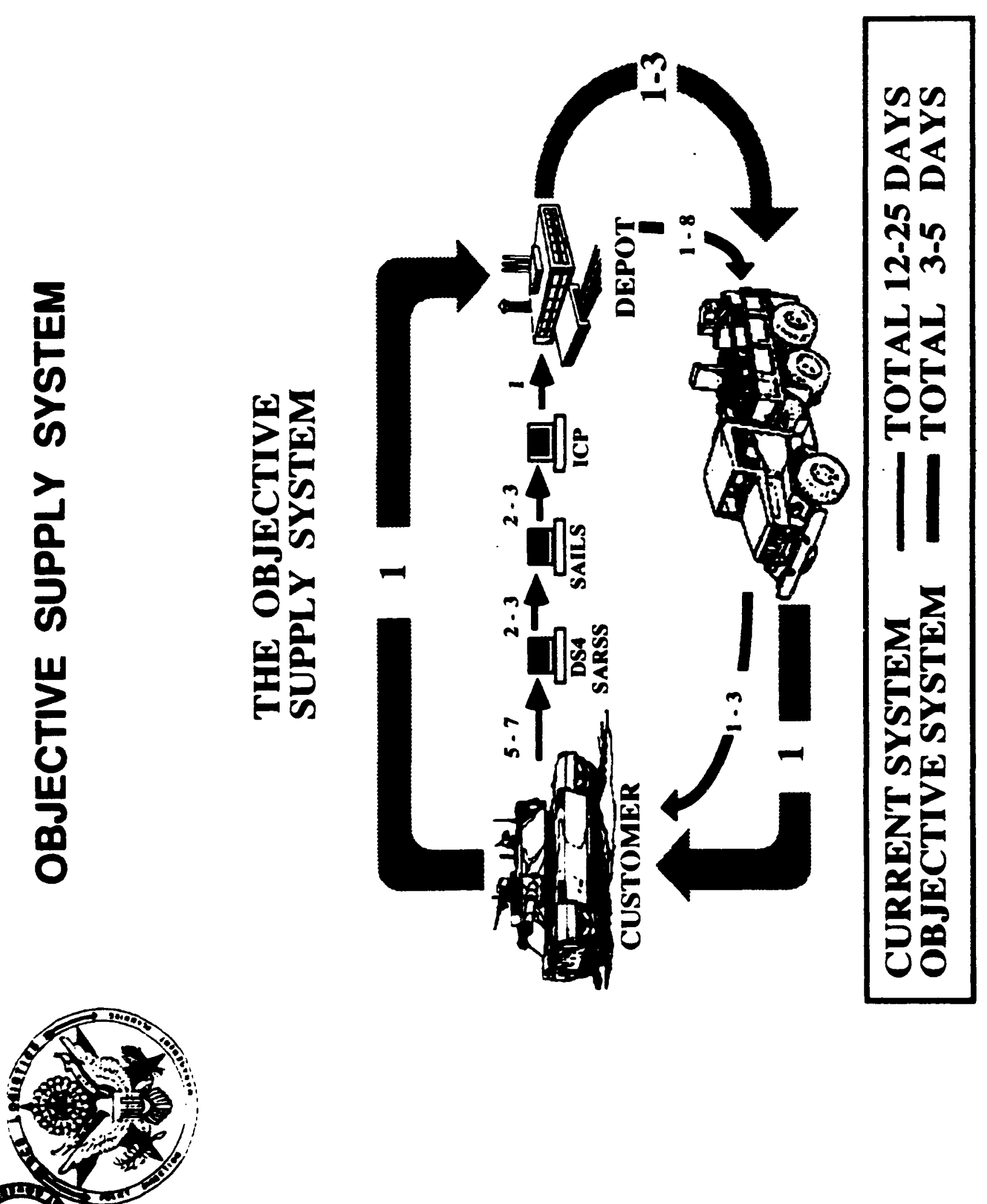

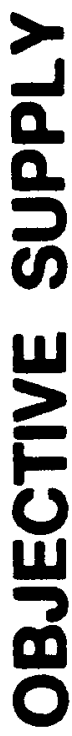

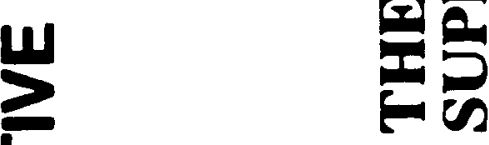




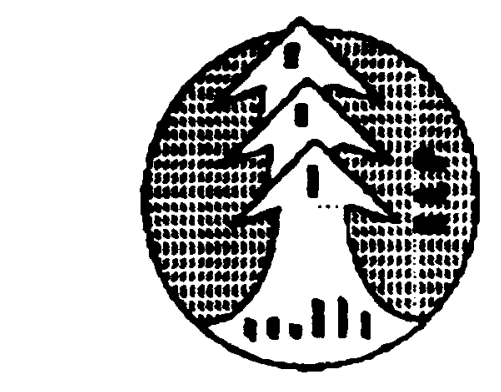

3

(0)

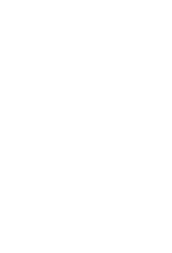

5

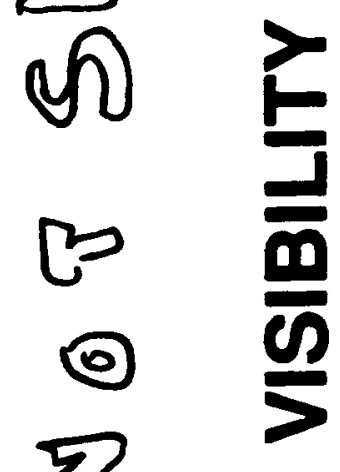

己

11
0
0

0
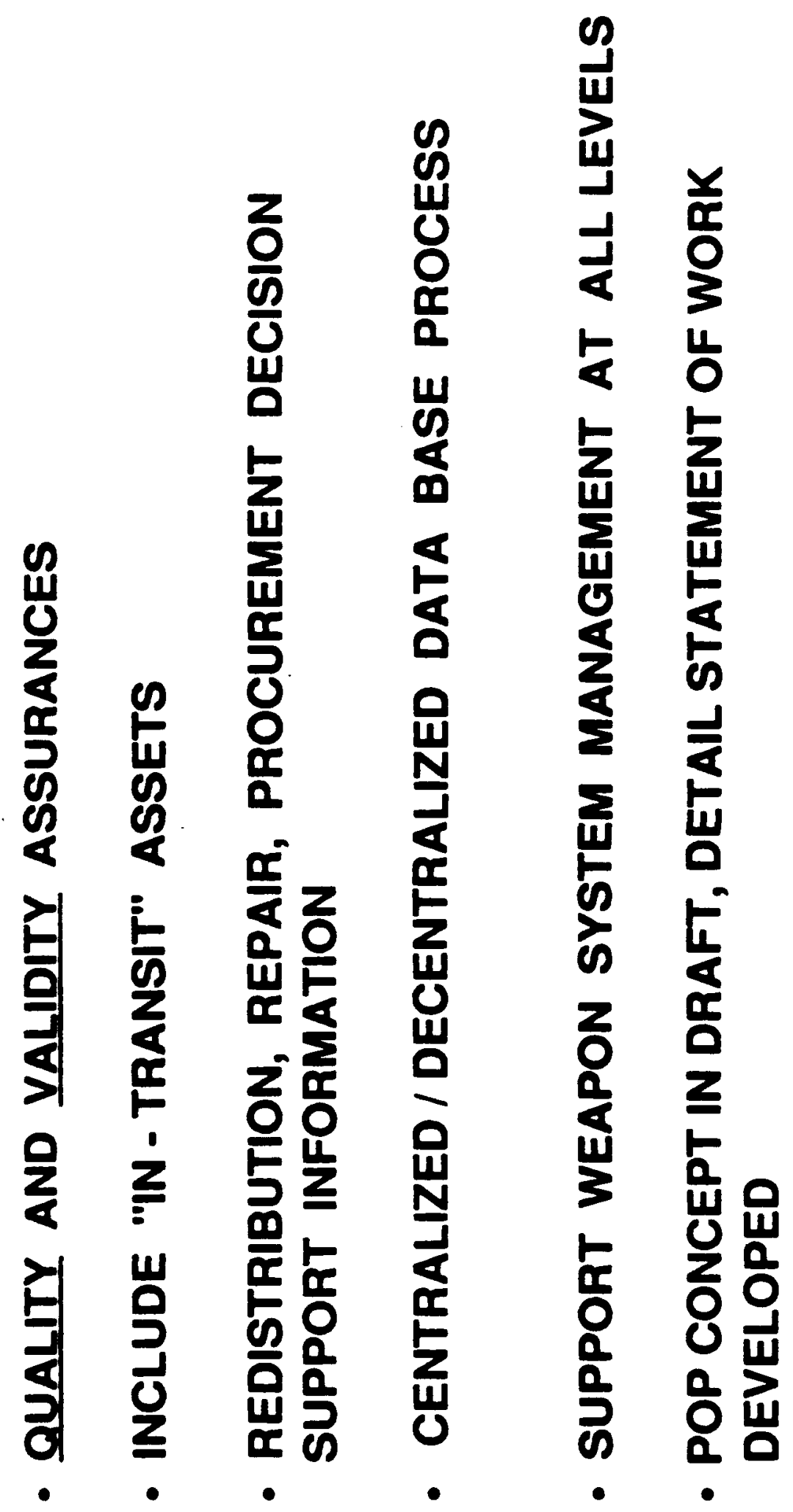

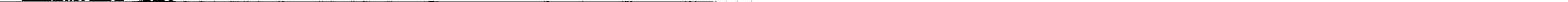

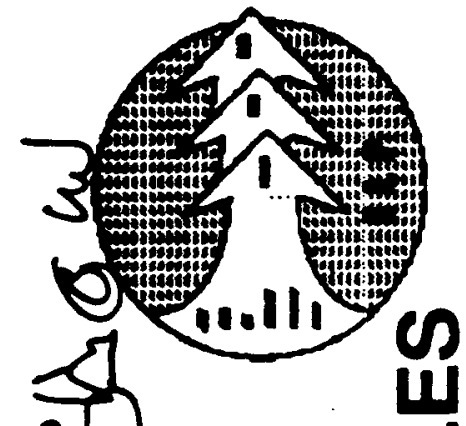

ल)

?

0

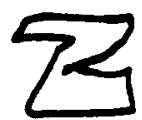

0

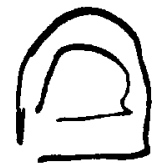

\section{II}

a

$<$

들

4

a

II

$\boldsymbol{\alpha}$

II

$>$

III

II

F

0

ํ.

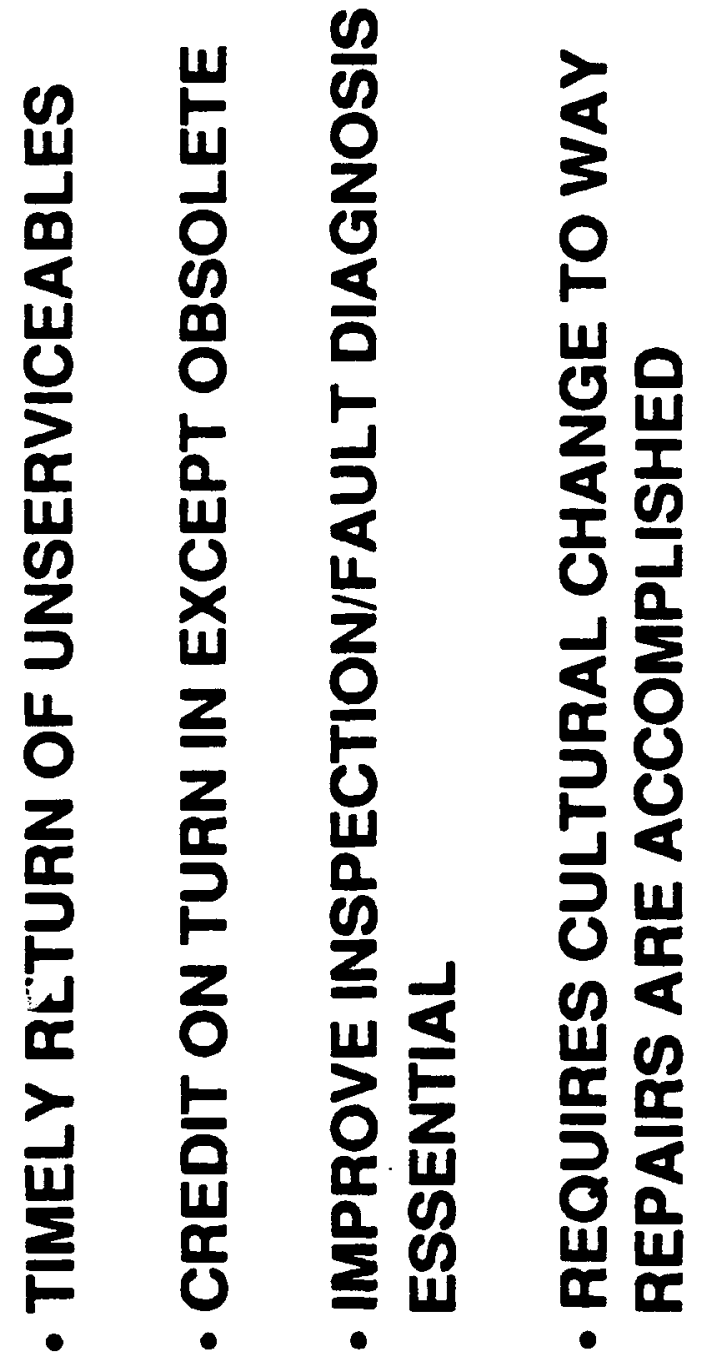

6360.

ด
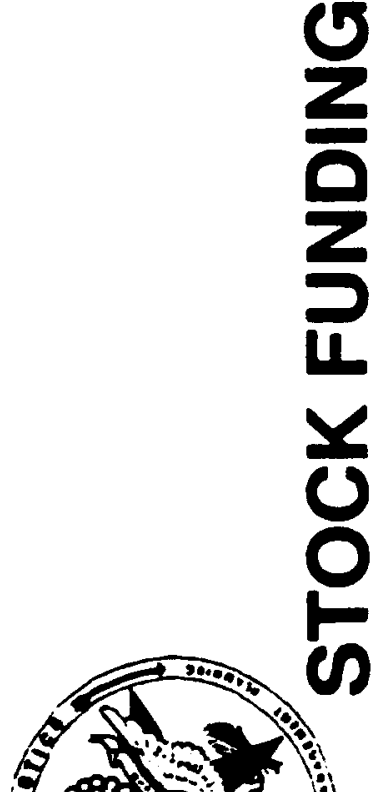

9 ant -8

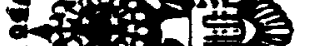
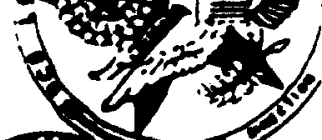

$(1)_{1}, 2 x+1$ 

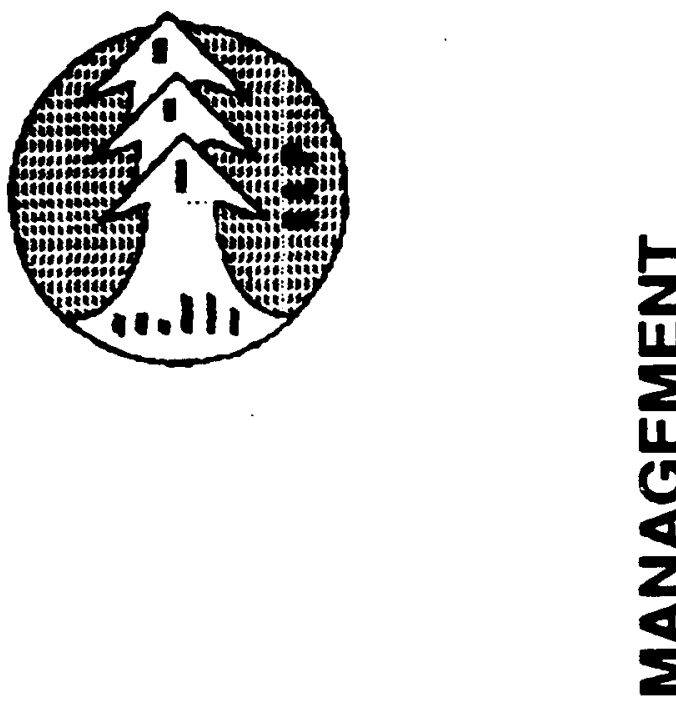

$\frac{2}{4}$

60360

ento

禺

$\infty$

III
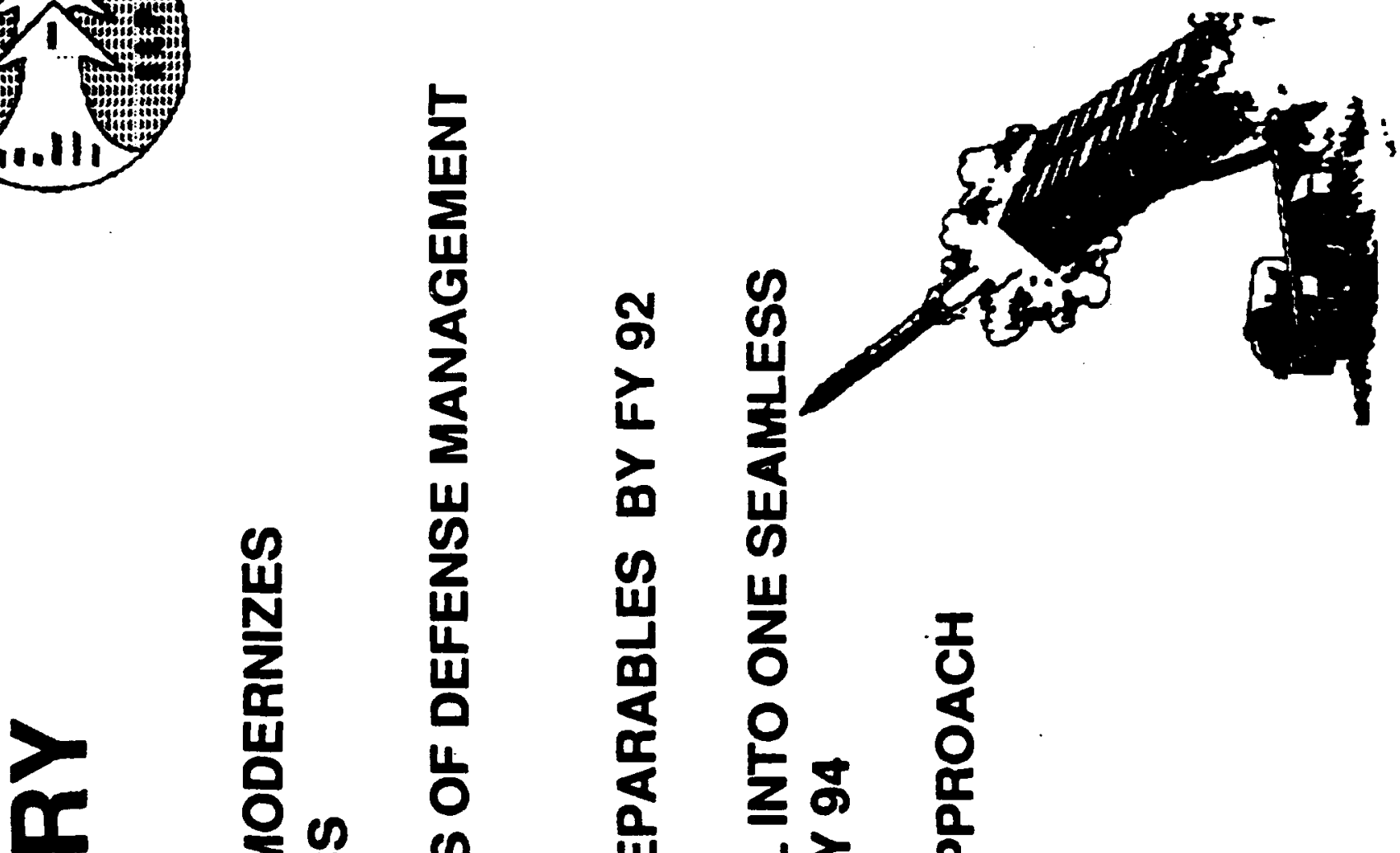

II

(3)

$\sum$ in

iv

II)

Q 14

ำ

(

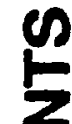

$-5$

$\infty \frac{\pi}{6}=$

(3) II

어

$\frac{5}{8}$

今

a 20

$\underline{0}$

II

0

c

里

บ

co

$9 \% \sum \frac{1}{0}$

땅유 क क

क क

언

미

플

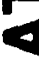

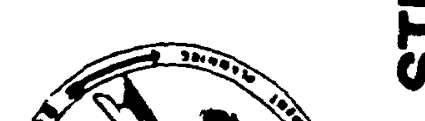

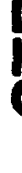

$\frac{1}{2}$

心

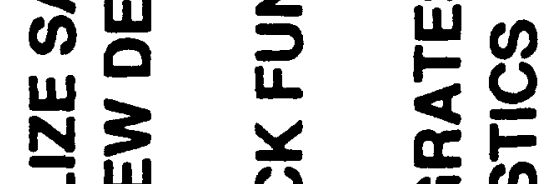

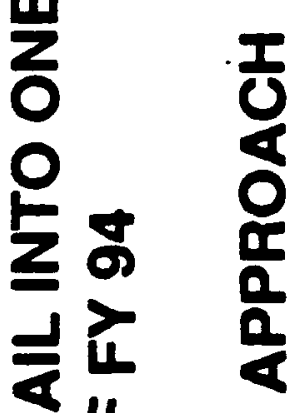

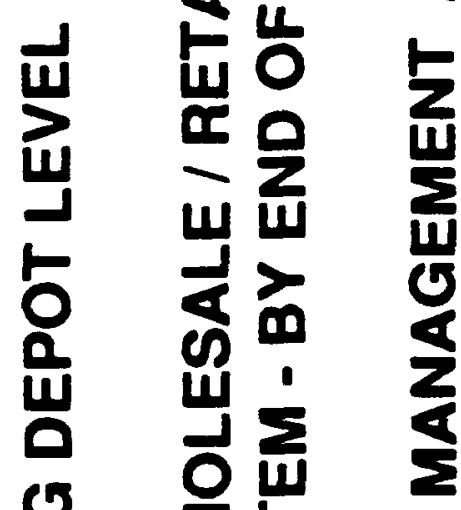

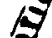

-

$\frac{1}{2}$

III

용

os

핑

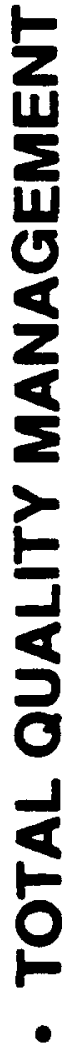

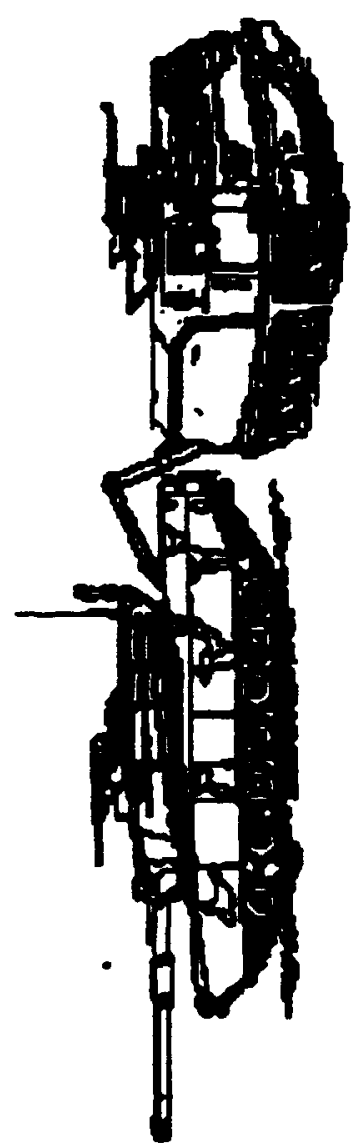

CIII: 

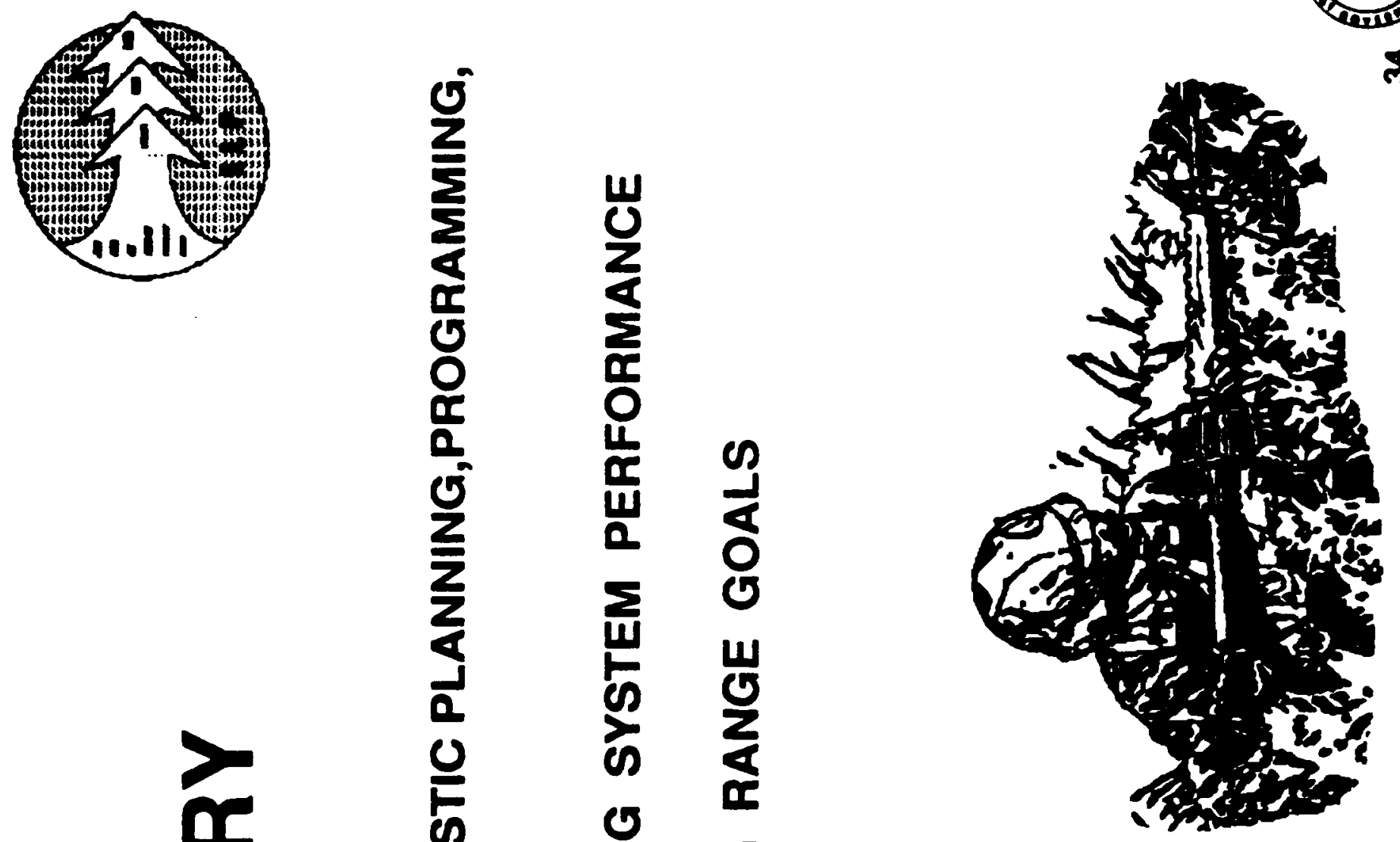

इ
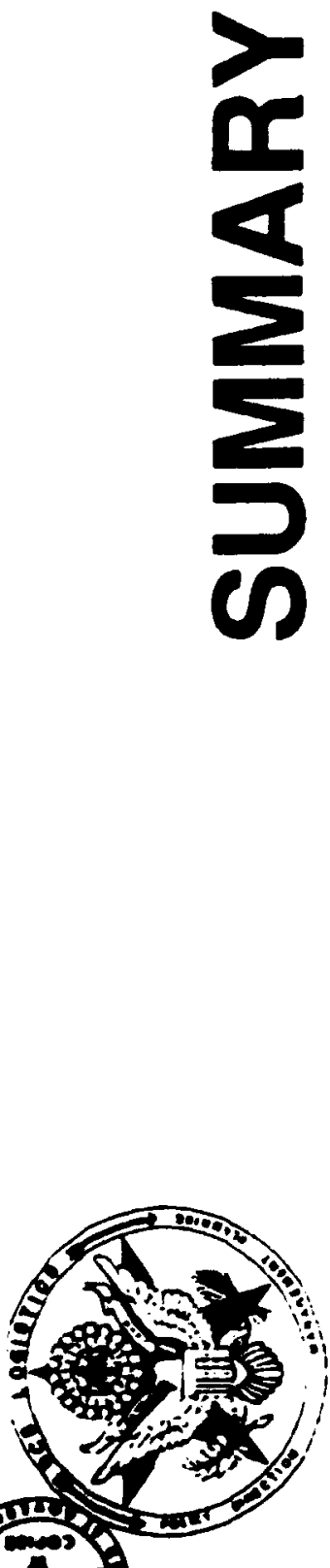

焉

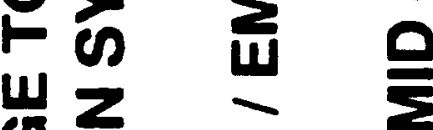

020
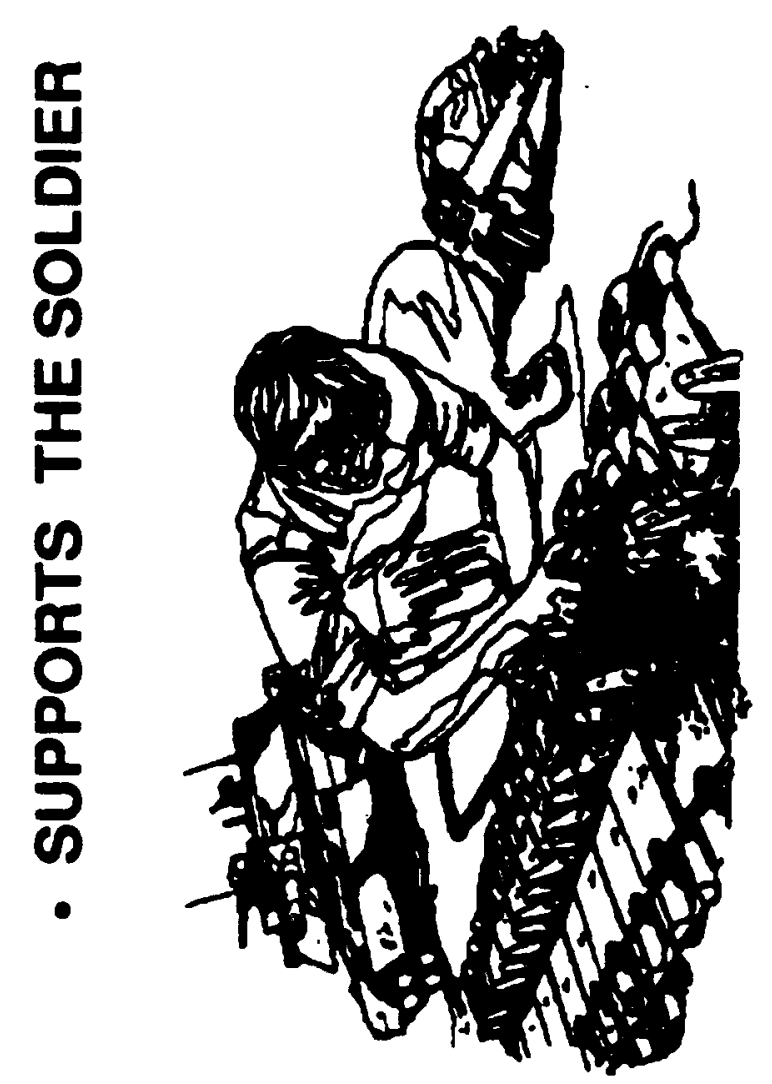

$\frac{2}{3}$ 